\title{
Modeling of biomass smoke injection into the lower stratosphere by a large forest fire (Part I): reference simulation
}

\author{
J. Trentmann ${ }^{1}$, G. Luderer ${ }^{2}$, T. Winterrath ${ }^{2}$, M. D. Fromm ${ }^{3}$, R. Servranckx ${ }^{4}$, C. Textor ${ }^{5}$, M. Herzog ${ }^{6}$, H.-F. Graf ${ }^{7}$, \\ and M. O. Andreae ${ }^{2}$ \\ ${ }^{1}$ Institute for Atmospheric Physics, Johannes Gutenberg University Mainz, Mainz, Germany \\ ${ }^{2}$ Max Planck Institute for Chemistry, Dept. Biogeochemistry, Mainz, Germany \\ ${ }^{3}$ Naval Research Laboratory, Washington, D.C., USA \\ ${ }^{4}$ Meteorological Service of Canada, Montreal, Canada \\ ${ }^{5}$ Service d'Aéronomie, CNRS, Paris, France \\ ${ }^{6}$ NOAA GFDL, Princeton, NJ, USA \\ ${ }^{7}$ Department of Geography, Centre of Atmospheric Science, University of Cambridge, Cambridge, UK
}

Received: 12 June 2006 - Published in Atmos. Chem. Phys. Discuss.:

Revised: - Accepted: 26 June 2006 - Published: 17 November 2006

\begin{abstract}
Wildland fires in boreal regions have the potential to initiate deep convection, so-called pyro-convection, due to their release of sensible heat. Under favorable atmospheric conditions, large fires can result in pyro-convection that transports the emissions into the upper troposphere and the lower stratosphere. Here, we present three-dimensional model simulations of the injection of fire emissions into the lower stratosphere by pyro-convection. These model simulations are constrained and evaluated with observations obtained from the Chisholm fire in Alberta, Canada, in 2001. The active tracer high resolution atmospheric model (ATHAM) is initialized with observations obtained by radiosonde. Information on the fire forcing is obtained from ground-based observations of the mass and moisture of the burned fuel. Based on radar observations, the pyroconvection reached an altitude of about $13 \mathrm{~km}$, well above the tropopause, which was located at about $11.2 \mathrm{~km}$. The model simulation yields a similarly strong convection with an overshoot of the convection above the tropopause. The main outflow from the pyro-convection occurs at about $10.6 \mathrm{~km}$, but a significant fraction (about $8 \%$ ) of the emitted mass of the smoke aerosol is transported above the tropopause. In contrast to regular convection, the region with maximum updraft velocity in the pyro-convection is located close to the surface above the fire. This results in high updraft velocities $>10 \mathrm{~m} \mathrm{~s}^{-1}$ at cloud base. The temperature anomaly in the plume decreases rapidly with height from values above $50 \mathrm{~K}$ at the fire to about $5 \mathrm{~K}$ at about $3000 \mathrm{~m}$ above the fire. While
\end{abstract}

Correspondence to: J. Trentmann

(jtrent@uni-mainz.de) the sensible heat released from the fire is responsible for the initiation of convection in the model, the release of latent heat from condensation and freezing dominates the overall energy budget. Emissions of water vapor from the fire do not significantly contribute to the energy budget of the convection.

\section{Introduction}

Emissions from wildland fires contribute significantly to the budgets of numerous atmospheric trace gases and aerosol particles (Crutzen and Andreae, 1990; Andreae and Merlet, 2001). In contrast to most other surface emissions (e.g., combustion of fossil fuel, dust) emissions from wildland fires are typically colocated with atmospheric convection, so-called pyro-convection, induced by the emission of sensible heat from the fire. The intensity of pyro-convection and therefore the vertical lifting of the fire emissions depends on the size and type of the wildland fire and the convective potential of the atmosphere. Especially in boreal regions, large, intense crown fires combined with conditionally unstable atmospheric conditions can lead to extreme convection with the potential to transport fire emissions into the upper troposphere (UT) and even into the lower stratosphere (LS).

Emissions from boreal biomass burning have regularly been observed in the UT/LS region using remote sensing (satellite and ground based) and in situ instrumentation. Waibel et al. (1999) measured enhanced concentrations of carbon monoxide (CO) from boreal fires in Canada in the UT/LS region over Europe in the summer of 1994. In the summer of 2002, Jost et al. (2004) found particulate and

Published by Copernicus GmbH on behalf of the European Geosciences Union. 
gaseous emissions from a Canadian fire in the stratosphere close to Florida, USA. Also above Florida, enhanced concentrations of methyl cyanide $\left(\mathrm{CH}_{3} \mathrm{CN}\right)$ from fires in Idaho were detected by the Microwave Limb Sounder (MLS) in the lower stratosphere in 1992 (Livesey et al., 2004). Siebert et al. (2000) report LIDAR measurements of a stratospheric aerosol layer over Sweden, likely originating from a Canadian wildfire in 1998. Satellite measurements demonstrated that this smoke layer extended over large areas (Fromm et al., 2000, 2005). Enhanced CO concentrations in the UT/LS region originating from Siberian fires in 2003 were found over Asia and over Europe (Nedelec et al., 2005; Immler et al., 2005). LIDAR measurements over Wisconsin, USA, in 2004 showed an upper tropospheric smoke layer resulting from fires in Alaska and the Yukon Territory (Damoah et al., 2006).

To understand the processes associated with intense pyroconvection, detailed information on the fire emissions and the atmospheric conditions is required. Some observational studies of pyro-convection events from prescribed fires are available. These studies often focussed on processes associated with the fires themselves (e.g., the Bor fire, FIRESCAN Science Team, 1996). Other studies provide insights into pyro-convection, but not much information about the fire behavior is available (e.g., the Battersby and the Hardiman fires, Radke et al., 1988, 1991; Banta et al., 1992). More comprehensive datasets are available for the Quinault fire at the U.S. West Coast (Hobbs et al., 1996; Gassó and Hegg, 1998), the Timbavati fire in South Africa (Hobbs et al., 2003), and from the International Crown Fire Modeling Experiment (ICFME) in Canada's Northwestern Territories (Stocks et al., 2004). None of these prescribed fires, however, resulted in cloud formation and deep convection.

There are few documented wildland fires that provide evidence for direct injection of smoke into the UT/LS region by pyro-convection leading to long-time and large-scale pollution. Satellite imagery provided evidence that direct emission by Canadian forest fires through pyro-convection was responsible for enhanced stratospheric aerosol optical depth in the summer of 1998 (Fromm et al., 2000, 2005). In May 2001, the Chisholm Fire, Alberta, Canada, induced a pyroconvection that led to the formation of a deep convective cloud, which penetrated the tropopause, and deposited smoke into the boreal stratosphere (Fromm and Servranckx, 2003; Rosenfeld et al., 2006). Extensive fires near Canberra, Australia, in 2003 lead to a fire-induced cumulonimbus $(\mathrm{Cb})$, a so-called pyroCb, that reached up to an altitude of $14 \mathrm{~km}$, i.e., well into the stratosphere (Mitchell et al., 2006; Fromm et al., 2006a).

Whereas there is some observational information on pyroconvection, very limited research has been conducted using numerical models. Most of the previous approaches to simulate convection induced by a fire or other surface heat sources have been performed with simplified models. Based on observations, Lavoué et al. (2000) derive a linear cor- relation between the injection height and the fire intensity. Buoyant plume and parcel models are used to estimate the height of the pyro-convection (e.g., Morton et al., 1956; Manis, 1985; Jenkins, 2004). Two-dimensional axis-symmetric models including simple cloud parameterizations were used for a more detailed description of the transport and entrainment (e.g., Small and Heikes, 1988; Gostintesev et al., 1991). The first three-dimensional model simulations of fire plumes were presented by Penner et al. (1986) for rather idealized scenarios and for the pyro-convection induced by the Hardiman Fire (Penner et al., 1991). Results from the latter simulation were combined with a parcel model to investigate the scavenging of smoke aerosol and cloud formation (Chuang et al., 1992). Recently, Cunningham et al. (2005) presented results from detailed simulations of the small scale dynamical interaction between the fire-induced buoyancy and the atmospheric wind.

In parallel to these models, which focus on the pyroconvection, numerical models that include the interaction between the atmosphere and fire have been developed and applied (e.g., Clark et al., 1996, 2004; Linn et al., 2005). These kinds of models, however, do not resolve the full dynamical evolution of deep pyro-convection involving cloud formation, and are not easily applicable to atmospheric studies.

The first detailed comparison of model results with field observations from a young biomass burning plume was presented by Trentmann et al. (2002). They used observed atmospheric profiles of temperature, moisture and wind combined with information on the fire emissions to simulate the pyroconvection induced by the prescribed Quinault fire (Hobbs et al., 1996). Chemical processes leading to the formation of tropospheric ozone were also investigated (Trentmann et al., 2003a). In the case of the Quinault fire, the convection was not particularly intense, no cloud was formed, and the smoke aerosol remained in the boundary layer.

Here, we will present model simulations for the pyroconvection induced by the Chisholm fire (Fromm and Servranckx, 2003; Rosenfeld et al., 2006). This pyroconvection transported the fire emissions into the upper tropospheric region and into the stratosphere. The pyroCbconvection and the resulting stratospheric aerosol plume have been observed by radar and satellite (Fromm and Servranckx, 2003; Rosenfeld et al., 2006). This paper presents relevant information on the model and its initialization. Results from model simulations using the best-available data for the meteorological conditions and the fire emissions are shown and evaluated with field observations. Some dynamical features of the simulated pyroCb are discussed. In a companion paper, (Luderer et al., 2006a) present results from sensitivity studies exploring the impact of the fire emissions (sensible heat, water vapor, and $\mathrm{CCN}$ ) and the ambient background profiles on the simulated pyroCb. 


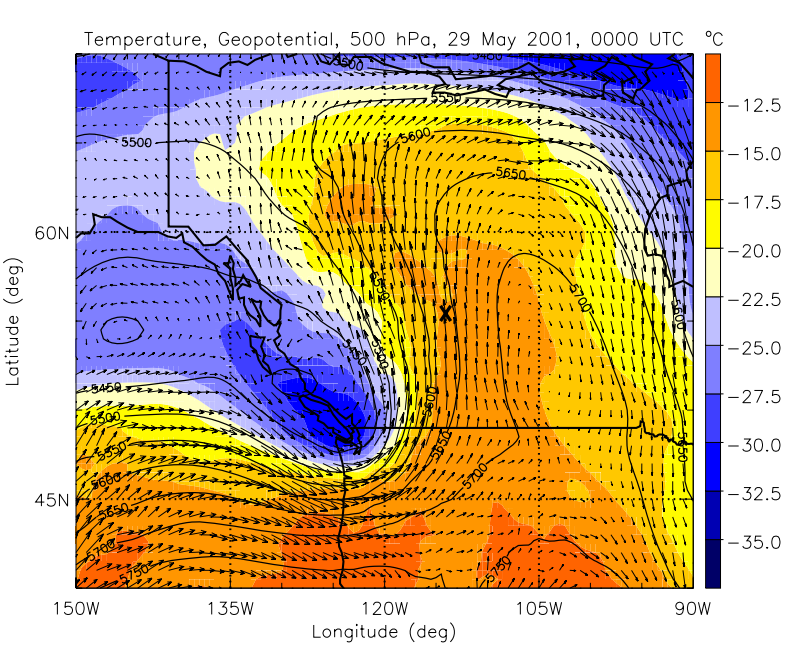

Fig. 1. Temperature (color scale), geopotential height (m, black contours), and wind field (arrows) at $500 \mathrm{hPa}$ from ECMWF analysis data for 29 May 2001, 00:00 UTC. The location of the Chisholm fire is depicted by the black cross at $55^{\circ} \mathrm{N}, 114^{\circ} \mathrm{W}$.

\section{Observations}

A wealth of information is available for the Chisholm fire. This includes extensive documentation of the fire behavior (ASRD, 2001) and remote sensing information of the fire and the pyroCb that developed atop of the fire (Fromm and Servranckx, 2003; Rosenfeld et al., 2006). Here, we focus on the information relevant for the present study.

\subsection{Fire observations}

The Chisholm Fire (tagged LWF-063), a man-caused forest fire, was ignited on 23 May 2001 at about $55^{\circ} \mathrm{N}, 114^{\circ} \mathrm{W}$, approx. $160 \mathrm{~km}$ north of Edmonton, Alberta, Canada (ASRD, 2001). In the afternoon of 28 May, a second fire was started (LWF-073) and later merged with Fire 063. Favorable weather conditions, in particular a strong low-level jet, and dry fuel led to erratic fire behavior and intense convection on 28 May, especially in the late afternoon and early evening. Fire intensity maximized on this day between about 17:00 and 24:00 MDT (Mountain Daylight Time), i.e., between 23:00 UTC and 06:00 UTC. During this time span, a total area of more than 50000 ha was impacted by the fire. The average rate of spread was observed to be $5.4 \mathrm{~km} \mathrm{~h}^{-1}$ $\left(=1.5 \mathrm{~m} \mathrm{~s}^{-1}\right)$. The main types of fuel burned (according to the Canadian Forest Fire Behavior Prediction (FBP) System) were boreal spruce and grass, which include substantial amounts of soil and duff. The fuel density in the area that burned during the time of peak fire activity is rather inhomogeneous. In its southern part, it is dominated by dense coniferous vegetation, while there are extended patches of grasslands in the northern part of the burnt area. Field sampling conducted after the fire yielded a fuel consumption of

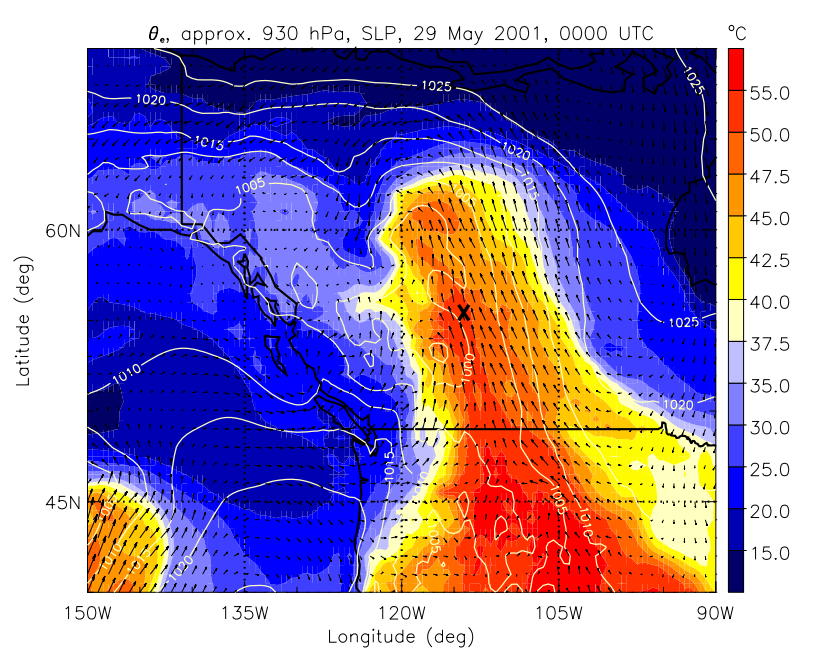

Fig. 2. Equivalent potential temperature, $\theta_{e}$, (color scale), normalized surface pressure ( $\mathrm{hPa}$, white contours), and wind field (arrows) at the 9th level of the vertical hybrid coordinate system (approx. $930 \mathrm{hPa}$ ) from ECMWF analysis data for 29 May 2001, 00:00 UTC. The location of the Chisholm fire is depicted by the black cross at $55^{\circ} \mathrm{N}, 114^{\circ} \mathrm{W}$.

$9.4 \mathrm{~kg} \mathrm{~m}^{-2}$ for the spruce forest (ASRD, 2001). Averaged over the entire area burned, the estimated fuel consumption at the time of the peak intensity is $7.6 \mathrm{~kg} \mathrm{~m}^{-2}$. The Fine Fuel Moisture Code (FFMC) and the Duff Moisture Code (DMC) of the Canadian Forest Service, which are measures of the moisture content of the fine fuel and the duff, respectively, were estimated to be 92.8 and 99 , respectively. These values correspond to moisture contents of fine fuel and duff of $8 \%$ and $49 \%$ of the dry fuel mass, respectively (Van Wagner, 1987). Considering the large consumption of duff of up to about 90\% (ASRD, 2001), we employ an overall fuel moisture content of the burned biomass of $40 \%$ of the dry fuel mass.

The total energy release due to combustion has been calculated from the average fuel burned, the affected area, and the standard heat of combustion $\left(18700 \mathrm{~kJ} \mathrm{~kg}^{-1}\right.$, ASRD, $2001)$. For the $7 \mathrm{~h}$ of maximum intensity this yields an overall energy release of about $71 \times 10^{9}$ MJ. This value can be converted into a TNT equivalent $\left(1 \mathrm{kT}\right.$ TNT $\left.=4.2 \times 10^{6} \mathrm{MJ}\right)$, which gives an energy release of the Chisholm fire corresponding to $17000 \mathrm{kT}$ TNT, corresponding to about 1200 times the energy release of the nuclear bomb that destroyed Hiroshima in August 1945 with a TNT equivalent of 12 $15 \mathrm{kT}$ TNT.

\subsection{Meteorological situation and observations of the Py- $\mathrm{roCb}$}

The meteorological situation on 28 May 2001 over Canada was characterized by a strong $500 \mathrm{mb}$ ridge with its western edge extending from about $45^{\circ} \mathrm{N}$ to $60^{\circ} \mathrm{N}$ along about $115^{\circ} \mathrm{W}$ (Fig. 1). 


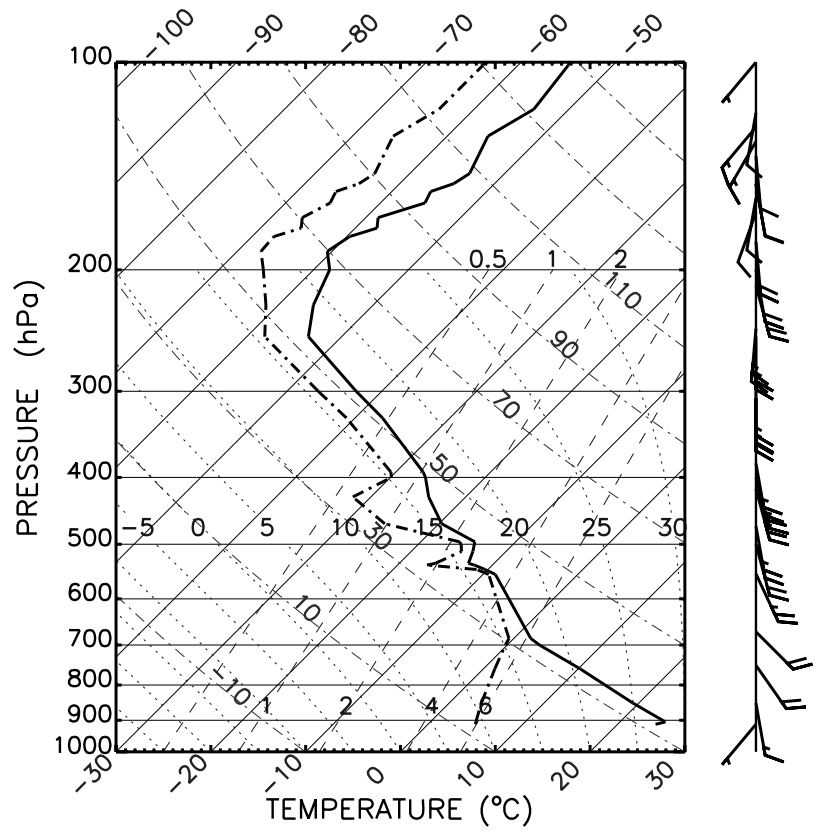

Fig. 3. Vertical profiles of temperature and dew point temperature used for the initialization of the model simulations.

Southerly winds were present along the ridge at all levels. The low level winds transported warm and moist airmasses towards the Chisholm area inducing unstable atmospheric conditions (Fig. 2).

West of the Chisholm area a local low pressure area formed with an associated trough and cold front that moved towards the fire area (ASRD, 2001). Based on radar and satellite observations (Rosenfeld et al., 2006), a first convective line of isolated cumulonimbus, associated with the upper trough, reached the fire plume at 20:30 UTC (=14:30 MDT). Strong south-easterly surface wind prevailed after the passage of this first convective line. The maximum surface temperature reached $28^{\circ} \mathrm{C}$ with a minimum relative humidity of $25 \%$ indicating high fire risk (ASRD, 2001). As a result of the unstable airmass behind the first line of $\mathrm{Cb}$, a second line of intense convection approached the fire area from southerly directions at about 23:00 UTC (=17:00 MDT). This convective line was more intense with maximum altitudes of radar reflectivity of about $10 \mathrm{~km}$ and widespread thunderstorm activity. A peak wind gust, influenced by downdrafts of the passing thunderstorm at the surface, of $92 \mathrm{~km} \mathrm{~h}^{-1}$ was measured at 00:00 UTC (ASRD, 2001).

During the passage of the first convective line, the fireinduced convection started to veer, but did not intensify. The fire-induced convection was substantially intensified between 23:30 UTC and 02:30 UTC, when the second convective line approached the fire (Rosenfeld et al., 2006). Two distinctive intense pyroCbs (blow-ups) were observed in this time frame. The first occurred between 23:30 UTC and 00:30 UTC with maximum echotop heights measured by the radar of about $12 \mathrm{~km}$. The second blow-up occurred between 01:20 UTC and 02:30 UTC with the arrival of the second line of convection at the fire location. Radar observations yield maximum heights for this pyro-convection between $13 \mathrm{~km}$ and $14 \mathrm{~km}$. Satellite observations at 02:00 UTC on 29 May 2001 show a well developed convective cloud anvil covering an area of about $50 \mathrm{~km} \times 100 \mathrm{~km}$ (Rosenfeld et al., 2006). An overshooting region slightly north of the fire on top of the anvil and gravity wave-like structures in the anvil are also visible. Other features of this pyro-convection include an anomalously high number of positive lightning strikes (Rosenfeld et al., 2006). In the present work, we focus on the second of this pair of intense pyro-convection events.

With the help of GOES- 8 satellite observations, the transport of the fire smoke in the upper troposphere/lower stratosphere was traced (Fromm and Servranckx, 2003). It was transported by the upper level wind fields towards the north and, at about 15:00 UTC on 29 May 2001, turned eastward, north of $60^{\circ} \mathrm{N}$. On 29 May 2001, 18:40 UTC, the Moderate Resolution Imaging Spectroradiometer (MODIS) and the Multi-angle Imaging SpectroRadiometer (MISR), both aboard the TERRA satellite, observed the smoke plume about $1200 \mathrm{~km}$ north of Chisholm. Using the information from MISR's different viewing angles, the maximum height of the smoke layer was determined to be about $13 \mathrm{~km}$, i.e, well in the stratosphere (http://eosweb.larc.nasa.gov/ HPDOCS/misr/misr_html/chisholm_forest_fire.html, Fromm et al. $\left.(2006 b)^{1}\right)$.

Figure 3 presents measurements taken from a radiosonde launched near Edmonton, Alberta (WMO Station Identifier $71119 ; 53.55^{\circ} \mathrm{N}, 114.10^{\circ} \mathrm{W}$ ) on 29 May 2001 at 00:00 UTC (available at http://raob.fsl.noaa.gov/). These measurements, taken approx. $150 \mathrm{~km}$ south of the Chisholm fire, are representative of the conditions before the second line of convection has reached Chisholm. While the atmospheric boundary layer was not particularly moist (absolute humidity $q_{v}=6 \mathrm{~g} \mathrm{~kg}^{-1}$ ), the middle troposphere above $700 \mathrm{hPa}$ (corresponding to $3000 \mathrm{~m}$ above sea level (asl)) was almost saturated. Below $700 \mathrm{hPa}$ the temperature approximately followed a dry adiabatic decrease with altitude, above $700 \mathrm{hPa}$ the lapse rate was slightly larger than the moist-adiabatic lapse rate.

With its rather low convective available potential energy (CAPE) of $131 \mathrm{~J} \mathrm{~kg}^{-1}$, this profile does not indicate the potential for significant convection, whereas the value for the convective inhibition (CIN) of $26 \mathrm{~J} \mathrm{~kg}^{-1}$ suggests easy initiation of convection. The lifting condensation level (LCL), the level of free convection (LFC), and the level of neutral buoyancy (LNB) of the background profile are located at $3250 \mathrm{~m}$,

\footnotetext{
${ }^{1}$ Fromm, M., Shettle, E., Torres O., Diner, D., Khan, R., Servranckx, R., and Vant Hull, B., The stratospheric impact of the Chisholm pyrocumulonimbus, Part I: the nadir-viewer story (TOMS, MODIS, MISR), in preparation, 2006b.
} 
$3620 \mathrm{~m}$, and $7410 \mathrm{~m}$ respectively. The $0^{\circ} \mathrm{C}$-level is at about $3400 \mathrm{~m}$, i.e., close to the LCL. The thermal tropopause based on the WMO-definition is located at $12.3 \mathrm{~km}$, corresponding to a pressure of $180 \mathrm{hPa}$ and a potential temperature of $345 \mathrm{~K}$. Based on ECMWF analysis data, the dynamical tropopause ( $\mathrm{PV}>2 \mathrm{PVU}$ ) was located at a potential temperature of $\theta=332 \mathrm{~K}$, corresponding to an altitude of $\mathrm{z}=11.2 \mathrm{~km}$ and a pressure of $\mathrm{p}=225 \mathrm{hPa}$. Here, we chose to use the PV-definition of the tropopause, which is more meaningful for studies of the troposphere-stratosphere exchange in midlatitudes (e.g., Holton et al. (1995); Stohl et al. (2003)).

\section{Model description}

The non-hydrostatic active tracer high resolution atmospheric model (ATHAM) (Oberhuber et al., 1998; Herzog et al., 2003) is used to simulate the pyro-convection induced by the Chisholm fire. ATHAM was originally designed and applied to simulate eruptive volcanic plumes (Graf et al., 1999). It was used to investigate the particle aggregation in an explosive volcanic eruption (Textor et al., 2006b), the impact of latent heat release and environmental conditions on the volcanic plume rise (Herzog et al., 1998; Graf et al., 1999), and the stratospheric injection of trace gases by explosive volcanic eruptions (Textor et al., 2003). It was also employed to simulate the transport of fire emissions (Trentmann et al., 2002) and the chemical processes leading to photochemical production of tropospheric ozone (Trentmann et al., 2003a). And, results obtained from ATHAM simulations were used to investigate three-dimensional radiative effects in a smoke plume (Trentmann et al., 2003b).

ATHAM is formulated with a modular structure that allows the inclusion of independent modules. Existing modules treat the dynamics, turbulence, tracer transport, cloud microphysics, gas scavenging, radiation, emissions, and chemistry. In the present investigation, only the dynamics, transport, turbulence, and cloud microphysics modules of ATHAM are used. The dynamics part solves the NavierStokes equation for a gas-particle mixture including the transport of active tracers (Oberhuber et al., 1998). Active tracers can occur in any concentrations. They modify the density and heat capacity of the grid box average quantities, and can have a strong impact on the dynamics of the system. In the present study, the aerosol particles and all hydrometeor classes are considered as active tracers. The turbulence scheme distinguishes between horizontal and vertical turbulence exchange processes (Herzog et al., 2003). It is based on a set of three coupled prognostic equations for the horizontal and vertical turbulent kinetic energy and the turbulent length scale.

Cloud microphysical processes are simulated using a twomoment scheme that predicts the numbers and mass mixing ratios of four classes of hydrometeors (cloud water, cloud ice, rain, graupel) and water vapor (Textor et al., 2006a).
The size distribution of each mode is represented by a generalized gamma function. In total 13 processes that transfer water between the five classes (four classes of hydrometeors and water vapor) are included in the scheme. These include water vapor transfer processes (i.e., condensation at and evaporation of liquid droplets as well as deposition at and sublimation on ice particles) based on the approach by Byers (1965), autoconversion of cloud water/cloud ice into the rain/graupel class, respectively, based on the approach by Murakami (1990), accretion due to a differential fall velocity between different hydrometeor classes (Textor et al., 2006a), and freezing of supercooled water following the stochastic approach of Bigg (1953). Within this approach, commonly used in microphysical parameterizations in convective cloud models (e.g., Reisin et al. (1996); Seifert and Beheng (2006)), the potential of the smoke particles to act as ice nuclei (IN) is not explicitly taken into account. Observations suggest that smoke particles can act as IN (Hobbs and Locatelli, 1969), but large uncertainties remain. Therefore the stochastic hypothesis for freezing of droplets seems appropriate for the present study. At temperatures below -36 ${ }^{\circ} \mathrm{C}$, homogeneous freezing is considered in the model simulations (Pruppacher and Klett, 1997).

The activation of aerosol particles cannot be treated explicitly in parameterized microphysical schemes. Sensitivity studies were conducted using a cloud parcel model with explicit treatment of aerosol activation (Simmel and Wurzler, 2006). The influence of the aerosol number concentration, the aerosol size distribution, the vertical velocity, and the soluble fraction of the aerosol on the fraction of activated aerosol particles has been investigated (Martin Simmel, personal communication, 2003). In these model simulations, the number of activated smoke particles, i.e., the number of aerosol particles that act as cloud condensation nuclei, was most sensitive to the aerosol number concentration. For the high number concentration typically found in pyro-convection $\left(>80000 \mathrm{~cm}^{-3}\right)$, only a very small fraction of the aerosol particles becomes activated. Based on the cloud parcel model results, we assume in ATHAM that 5\% of the smoke aerosol particles act as CCN. The exact value of the activated aerosol fraction used here for the conditions in pyro-convection must be considered a rough estimate.

However, it was found that the microphysically induced effect of the fire aerosols on dynamics is rather small (Luderer et al., 2006a). This justifies the simplified approach used here. The simplification limits, however, the use of ATHAM for detailed microphysical studies on the aerosol effect on the evolution and the precipitation efficiency of pyro-convection. Work is in progress to implement a more complex cloud microphysical scheme that includes the activation of aerosol (Khain et al., 2004).

ATHAM is three-dimensionally formulated with an implicit time-stepping scheme. The solution of the NavierStokes equation is computed on a cartesian grid. A grid stretching allows the use of a higher spatial resolution in 
predefined regions of the model domain than at the model boundaries. A mass-conservative form of the transport equation is employed for all tracers.

The focus of this study is the detailed description of the impact of fire emissions on the atmosphere in the vicinity of the fire on a horizontal scale of about $100 \mathrm{~km}$. The fluxes from the fire to the atmosphere are prescribed, and therefore not modified by the meteorological conditions, e.g., the wind speed and direction. The reduced requirements for computer resources allow a detailed description of the atmospheric processes related to fire-induced convection. Other numerical models that include the interaction between the atmosphere and fire result in a more realistic fire evolution and small scale features of the atmospheric fields (Clark et al., 2004; Linn et al., 2005). However, they do not consider all relevant processes (e.g., cloud microphysics) to describe the evolution of deep pyro-convection on the timescale considered here.

\section{Model setup and initialization}

For the present study, ATHAM is initialized to realistically represent the conditions of the convective event induced by the Chisholm fire.

The model domain was set to $84 \mathrm{~km} \times 65 \mathrm{~km} \times 26 \mathrm{~km}$ with $110 \times 85 \times 100$ grid boxes in the $\mathrm{x}-, \mathrm{y}-$, and $\mathrm{z}$-directions, respectively. The minimum horizontal grid box size was set to $500 \mathrm{~m}$ and $100 \mathrm{~m}$ in the $\mathrm{x}$ - and $\mathrm{y}$-directions, respectively. Due to the stretched grid, the size of the grid boxes increases towards the borders of the model domain. The vertical grid spacing at the surface and the tropopause was set to $50 \mathrm{~m}$ and $150 \mathrm{~m}$, respectively. Outside these regions, slightly larger vertical grid spacings were used. The lowest vertical model level is located at $766 \mathrm{~m}$ a.s.l., corresponding to the lowest elevation available in the radiosonde data used for the model initialization, and close to the elevation of Chisholm of about $600 \mathrm{~m}$ (ASRD, 2001). Throughout the manuscript, model elevations are given in $\mathrm{m}$ asl. An adaptive dynamical timestep between $1 \mathrm{sec}$ and $3 \mathrm{sec}$ was used, determined online by the Courant-Friedrichs-Lewy (CFL) criterion $(\mathrm{CFL} \leq 0.8)$. The model simulation was conducted for $40 \mathrm{~min}$. Since flat topography is employed in the model simulations, the model spin-up time is substantially shorter than the simulation time.

The model domain was initialized horizontally homogeneously with measurements obtained from the radiosonde presented in Sect. 2.2, Fig. 3. Open lateral boundaries were used for the model simulations. The horizontal means of the directional wind speed $(\mathrm{u}, \mathrm{v})$ and of the specific humidity $\left(q_{v}\right)$ were nudged towards the initial profile at the lateral boundaries. The initial atmospheric profile has some potential for convection (see Sect. 2.2), however, without the heat flux from the fire the model would not produce such a deep convective cloud, given a level of neutral buoyancy of $7.4 \mathrm{~km}$ in the initial profile.

\subsection{Representation of the fire emissions}

The fire is represented in the model by time-constant fluxes of sensible heat, water vapor, and aerosol mass into the lowest vertical model layer. The fire front was approximately linear and extended from south-south-east to north-north-west at an angle of approximately $165^{\circ}$ to North. Note that the xaxis of the model coordinate frame was aligned with the fire front, such that the $\mathrm{x}$-direction of the model domain is at an angle of $165^{\circ}$ to North.

The actual length of the fire front was about $25 \mathrm{~km}$. Due to computational constraints, however, we only accounted for the southern $15 \mathrm{~km}$ of the fire front, which passed through densely forested area. The width of the fire front was set to $500 \mathrm{~m}$. The energy release from the fire was calculated based on a fuel loading of $9.0 \mathrm{~kg} \mathrm{~m}^{-2}$ and a value of $18700 \mathrm{~kJ} \mathrm{~kg}^{-1}$ for the heat of combustion. Based on the comparably high fuel load in the southern part of the fire front, we choose a higher-than-average fuel loading in the simulations. With the observed rate of spread of the fire front of $1.5 \mathrm{~m} \mathrm{~s}^{-1}$, the frontal intensity (Byram, 1959; Lavoué et al., 2000) of the simulated fire is about $250000 \mathrm{~kW} \mathrm{~m}^{-1}$. In the model, the fire fluxes are held constant throughout the simulation. Not enough information on the fire behavior is available to include a more realistic spatial and temporal distribution of the fire emissions. As part of this study, test simulations using a moving fire front have been conducted (not shown here), which showed no impact of the moving fire front on the model results.

There is significant uncertainty in the literature on how much of the energy, released by combustion, contributes to local heating of the atmosphere (sensible heat flux) and is available for convection, and how much of the energy is lost due to radiative processes. Commonly found estimates for the radiative energy are between nearly zero percent (Wooster, 2002; Wooster et al., 2005) and 50\% (McCarter and Broido, 1965; Packham, 1969). These estimates are based on laboratory studies or small scale fires and their application to large scale crown fires resulting in pyroCb convection remains highly uncertain. Additional uncertainty exists related to the fate of the radiative energy emitted by the fire. In the thermal infrared, where most of the fire radiation is emitted (Wooster, 2002), aerosols are rather inefficient absorbers. It is likely that most of the radiative energy from the fire is absorbed by cloud droplets or gaseous absorption at cloud base or in air masses that are entrained into the convection. In both cases the radiative energy from the fire is trapped in the lower part of the pyro-convection and therefore contributes to the convective energy. Considering these radiative processes in detail is not possible in the present model setup. Here, we assume that all energy released in the combustion process becomes available for convection. This assumption is consistent with the coupled fire-atmosphere model of Clark et al. (1996). In the companion paper, we present the sensitivity of the model results to assumptions of 


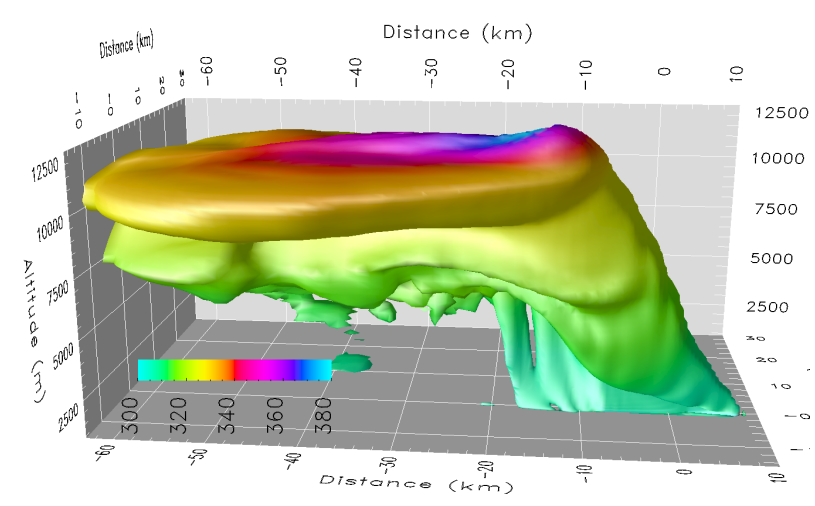

Fig. 4. Spatial distribution of the $150 \mu \mathrm{g} \mathrm{m}^{-3}$-isosurface of the simulated aerosol mass distribution after $40 \mathrm{~min}$ of simulation time. The color coding represents the potential temperature.

the release of sensible heat (Luderer et al., 2006a).

A small part of the energy released by the combustion of fuel is used to evaporate the fuel moisture. In the present study, a fuel moisture content of $40 \%$ was assumed (see Sect. 2.1), which takes up about 5\% of the total energy released by the combustion. Additional water vapor is released directly from the combustion process itself. Assuming complete combustion, $1 \mathrm{~kg}$ of fuel yields about $0.5 \mathrm{~kg}$ of combustion water vapor (Byram, 1959). In our simulations, about $8 \mathrm{~kg} \mathrm{~m}^{-2}$ water vapor was released, with the main contribution (about 55\%) coming from combustion moisture, leading to a total release of $4.7 \times 10^{8} \mathrm{~kg} \mathrm{H} 2 \mathrm{O}$. The particulate emissions from the fire were calculated using the emission factor of $17.6 \mathrm{~g} \mathrm{~kg}^{-1}$ from Andreae and Merlet (2001), assuming a volume mean diameter of $300 \mathrm{~nm}$ (Reid et al., 2005).

No detailed information on the wind direction at the location of the fire front at the time of the blow-up is available. Due to the complex meteorological situation (i.e., the approaching line of convection) it is likely that the local wind speed and wind direction were irregular and subject to rapid change. These effects cannot be represented with the model approach of this study. Therefore, we adopted the wind profile measured by the Edmonton radiosonde. Its surface wind direction is at an angle of about $30^{\circ}$ to the fire front. In the upper atmospheric levels, the ambient wind direction is parallel to the fire front. The angle between the wind field and the fire front has some impact on the average time that individual parcels are exposed to the fire.

\section{Model results}

In the following, results from the model simulations are presented. First, we will show the overall structure of the simulated pyroCb, and then investigate some dynamical features in more detail in Sect. 5.1.

Figure 4 shows the simulated extent of the $150 \mu \mathrm{g} \mathrm{m}^{-3}$. isosurface of the aerosol mass distribution after $40 \mathrm{~min}$ of

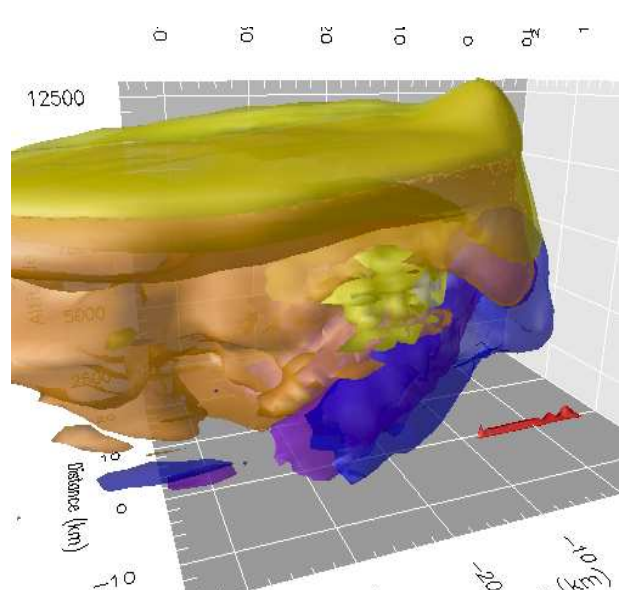

Fig. 5. Spatial distribution of the $0.4 \mathrm{~g} \mathrm{~kg}^{-1}$-isosurfaces of the simulated (blue) cloud water, (purple) rain water, (yellow) cloud ice, and (orange) graupel after $40 \mathrm{~min}$ of simulation time. Also indicated is the fire front (red) by the $45000 \mu \mathrm{g} \mathrm{m}^{-3}$-isosurface of the simulated aerosol mass distribution.

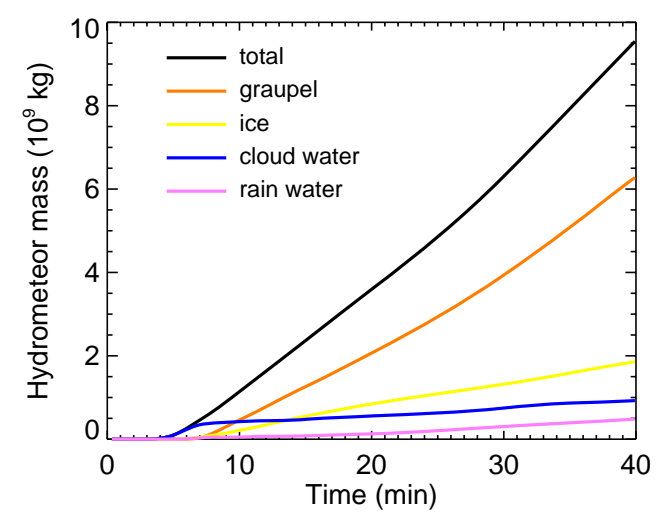

Fig. 6. Temporal evolution of the simulated integrated mass of the four classes of the microphysical scheme and the sum of the hydrometeors.

simulation time. The color coding represents the potential temperature. The assumed linear shape of the fire front is clearly visible as the origin of the convection and the source of the aerosol particles. The maximal height of the aerosol plume of about $12.5 \mathrm{~km}$ is reached above the fire. The plume reaches well into the stratosphere as can be inferred from the values of the potential temperatures above $332 \mathrm{~K}$. Large areas of the plume have a potential temperature of more than $340 \mathrm{~K}$. Downwind of the overshooting region, a relatively warm area develops in the anvil region with potential temperatures above $350 \mathrm{~K}$. This is consistent with the warm core of the Chisholm pyroCb observed by satellite (Fromm and Servranckx, 2003; Rosenfeld et al., 2006). A more detailed investigation of the plume top structures including an evaluation of the model results with satellite observations will be presented in Luderer et al. $(2006 \mathrm{~b})^{2}$.

\footnotetext{
${ }^{2}$ Luderer, G., Trentmann, J., Hungershöfer, K., et al.: The role of
} 

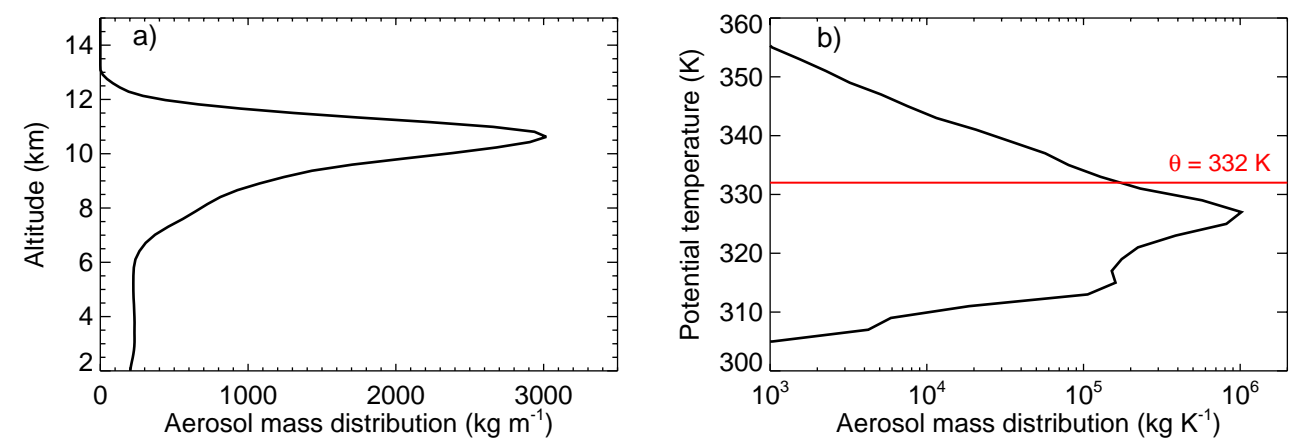

Fig. 7. Horizontally integrated aerosol mass as a function of (a) altitude and (b) potential temperature after 40 min of simulation. Note the logarithmic scale of the $\mathrm{x}$-axis in (b).

Figure 5 presents the spatial distribution of the $0.4 \mathrm{~g} \mathrm{~kg}^{-1}$ isosurfaces of the four hydrometeor classes (cloud water, rain, cloud ice, and graupel) at the end of the simulation. Graupel is the main contributor to the hydrometeor mass in the simulated pyroCb. It is interesting to note that cloud ice is dominant in the upper part of the cloud due to the sedimentation of the large hydrometeors. The size of the hydrometeors remains comparably small due to the high concentration of smoke aerosol acting as $\mathrm{CCN}$ and the large updraft velocities (Luderer et al., 2006a).

Figure 6 shows the temporal evolution of the spatially integrated mass of the four hydrometeor classes in the model domain. The first cloud water condenses after about $4 \mathrm{~min}$ of simulation time at an elevation of about $4.2 \mathrm{~km}$. The enhanced temperature in the plume leads to delayed condensation compared to the LCL derived from the initial background profile $(3.25 \mathrm{~km})$. After about $10 \mathrm{~min}$, the graupel class becomes the dominant class in the pyro-cloud. Cloud ice has the second largest contribution to the total hydrometeor mass followed by cloud and rain water.

Figure 7 shows the horizontally integrated aerosol mass as function of altitude and potential temperature after $40 \mathrm{~min}$ of simulation time. The main outflow height (defined as the height of the maximum of the vertically integrated aerosol distribution) and the maximum penetration height (defined as the height below which $99 \%$ of the aerosol mass is located) are $10.6 \mathrm{~km}$ and $12.1 \mathrm{~km}$, respectively. The outflow height is substantially higher than the level of neutral buoyancy calculated based on the sounding (7410 m, Sect. 2.2), due to the significant emissions of sensible heat from the fire. A substantial amount of aerosol mass is located at stratospheric potential temperature levels $(\theta>332 \mathrm{~K})$. Overall, $710 \mathrm{t}$ aerosol mass was deposited into the stratosphere, corresponding to about $8 \%$ of the total emitted aerosol mass. Whether the smoke aerosol will remain in the stratosphere

small scale processes in troposphere-stratosphere transport by pyroconvection, Atmos. Phys. Chem. Discuss., in preparation, $2006 \mathrm{~b}$. after the pyro-convection has deceased can not be evaluated with the present model setup that only allows model simulations for about $40 \mathrm{~min}$. The present simulation, however, does show that pyro-convection can be sufficiently intense to transport smoke aerosol across the tropopause and into the stratosphere.

To estimate the contribution of the latent heat release via condensation and freezing to the release of sensible heat by the fire, we calculate the total heat of condensation and freezing based on the total mass of hydrometeors in the model domain $\left(8.22 \times 10^{9} \mathrm{~kg}\right.$ frozen hydrometeors, $1.4 \times 10^{9} \mathrm{~kg}$ liquid hydrometeors) to be $26.8 \times 10^{9} \mathrm{MJ}$. This value can be considered a lower estimate of the total energy release by condensation/freezing, since deposition of hydrometeors is neglected in this simplified estimate. This number can be compared to the total amount of sensible heat emitted from the fire during the simulation which sums up to $9 \times 10^{9} \mathrm{MJ}$. This estimate yields that about $25 \%$ of the total energy results from direct emission of sensible heat from the fire, while the dominant part of the energy budget can be attributed to the release of latent heat during condensation and freezing. Comparing the total water mass released from the fire $\left(4.7 \times 10^{8} \mathrm{~kg}\right.$, see Sect. 4.1) to the total mass of liquid and frozen hydrometeors in the plume $\left(9.62 \times 10^{9} \mathrm{~kg}\right)$ yields a contribution of the latent heat release from the fire of less than 5\% to the total energy released from condensation and freezing.

A similar estimate is obtained, when we consider an individual parcel in the upper part of the plume with an average aerosol mass concentration of $3000 \mu \mathrm{g} \mathrm{m}^{-3}$ and a hydrometeor concentration of about $5 \mathrm{~g} \mathrm{~kg}^{-1}$. Based on the emission ratios for sensible heat, water vapor, and particles, this parcel gained about $6 \mathrm{~K}$ of sensible heat and $0.3 \mathrm{~g} \mathrm{~kg}^{-1} \mathrm{H}_{2} \mathrm{O}$ from the fire. The hydrometeor concentration corresponds to a release of latent heat from condensation of about $12 \mathrm{~K}$. This parcel-based estimate yields a slightly larger contribution of the sensible heat flux from the fire to the parcel energy than the previous estimate based on the energy budget for the whole pyroCb. Both estimates highlight the importance of 


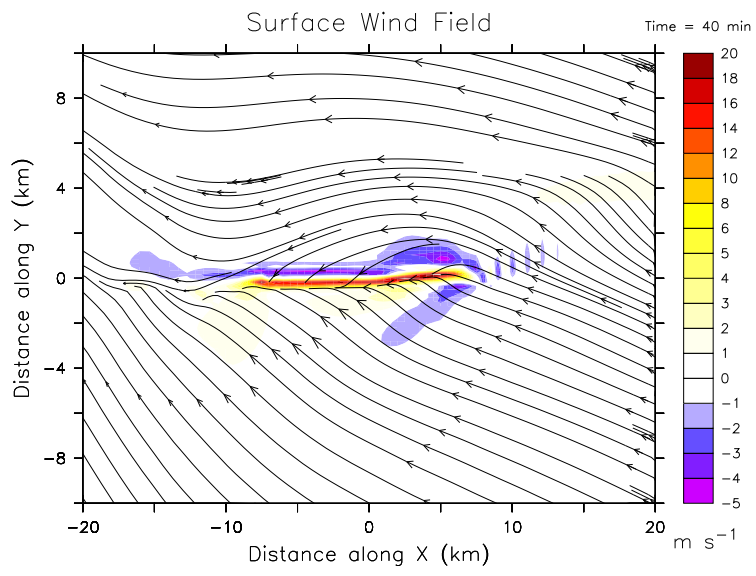

Fig. 8. Simulated wind field after $40 \mathrm{~min}$ of simulation time at $1000 \mathrm{~m}$ altitude. Streamlines indicate the horizontal wind, the vertical wind speed is indicated by the color coding.

the availability of ambient moisture for the evolution of the pyro-convection.

It must be noted, however, that a positive feedback exists between the sensible heat flux from the fire and the latent heat released in the plume (Luderer et al., 2006a). Enhancing the sensible heat flux enhances also the total latent heat release in the plume, probably because of enhanced entrainment of humid air at low levels and reduced entrainment of dry air at higher levels. Even though the latent heat dominates the overall energy budget of the plume, the sensible heat input is a critical parameter to determine the evolution of the pyroconvection (Luderer et al., 2006a).

In the following, some aspects of the evolution of the pyroconvection are discussed.

\subsection{Convection dynamics}

After the onset of the heat flux from the fire, convection immediately develops in the model simulations due to the positive temperature anomaly of the air in the lowest model layer above the fire.

Figure 8 presents streamlines of the horizontal wind and the vertical wind velocity at $1000 \mathrm{~m}$ a.s.l. (i.e., about $200 \mathrm{~m}$ a.g.l.) after $40 \mathrm{~min}$ of simulation. The fire clearly has a strong impact on the ambient wind field. The emission of sensible heat leads to high updraft velocities of up to $20 \mathrm{~m} \mathrm{~s}^{-1}$. The updraft results in the formation of a convergence of the horizontal wind. The simulated updraft velocities at the surface are signifcantly higher than those expected for regular convection. In the case of pyro-convection, the updraft initiates the convergence of the low-level horizontal wind, while regular convection often starts from low level wind convergence.

This wind modification is expected to significantly impact the evolution of the fire itself as has been shown in coupled

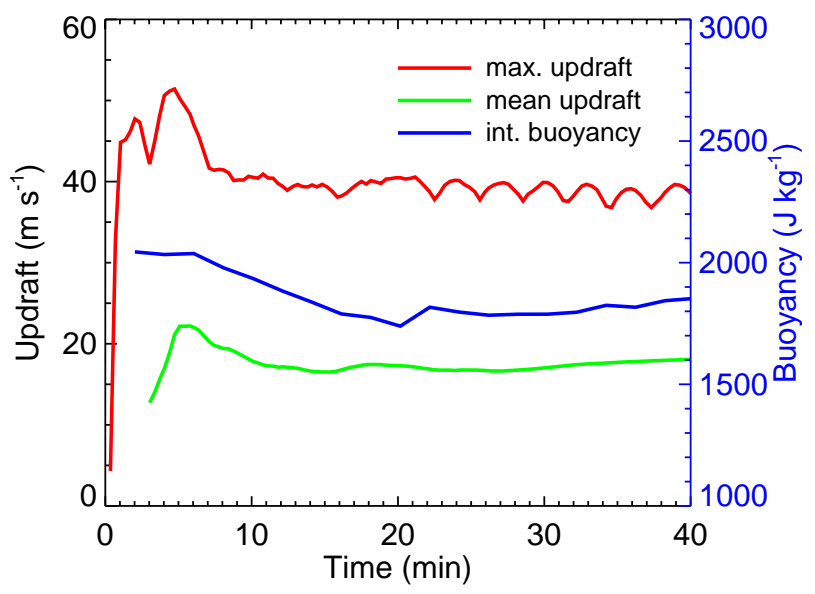

Fig. 9. Temporal evolution of the simulated maximum updraft velocity, $\mathrm{w}_{\max }$, the simulated mean updraft velocity, $\bar{w}$, and the simulated integrated buoyancy, $I B$.

atmosphere-fire simulations (Clark et al., 2004; Coen, 2005). Since the focus of this work is the investigation of the vertical transport of fire emissions, this feedback mechanism is not included here and the shape of the fire and the fire emissions are kept constant throughout the simulation.

Figure 9 shows the temporal evolution of some quantities used to characterize the dynamical evolution of the convection. Shown are the maximum vertical velocity, $w_{\max }$, the aerosol-mass-weighted mean vertical velocity, $\bar{w}$, and the integrated buoyancy, $I B . \bar{w}$ is defined by

$\bar{w}=\frac{1}{\int c_{a} \mathrm{~d} V} \int w c_{a} \mathrm{~d} V$.

$c_{a}$ is the aerosol mass concentration. The highest vertical velocities and aerosol loadings are located directly above the fire. To investigate processes in the pyroCb and compare different model simulations, this region, which is dominated by the fire emissions, needs to be excluded from the calculations. Therefore, we limit the calculation of the mean velocity to grid boxes with a hydrometeor content of more than $0.05 \mathrm{~g} \mathrm{~kg}^{-1}$. By including only grid boxes with a vertical velocity $w \geq 5 \mathrm{~m} \mathrm{~s}^{-1}$ we limit this estimate to strong updrafts. $I B$ is defined by

$I B=\int_{Z_{0}}^{Z_{\mathrm{LNB}}} \bar{b}(z) \mathrm{d} z$,

where the integration is performed from ground level $z_{0}$ to the level of neutral buoyancy $z_{\mathrm{LNB}}$ with $\bar{b}\left(z_{\mathrm{LNB}}\right)=0 . \quad \bar{b}(z)$ is the average buoyancy in the updraft calculated using the vertical aerosol flux as the weight function (see Luderer et al., 2006a for a full description of these quantities).

After about 20 min of simulation time, all quantities shown in Fig. 9 remain relatively constant, indicating that at least 


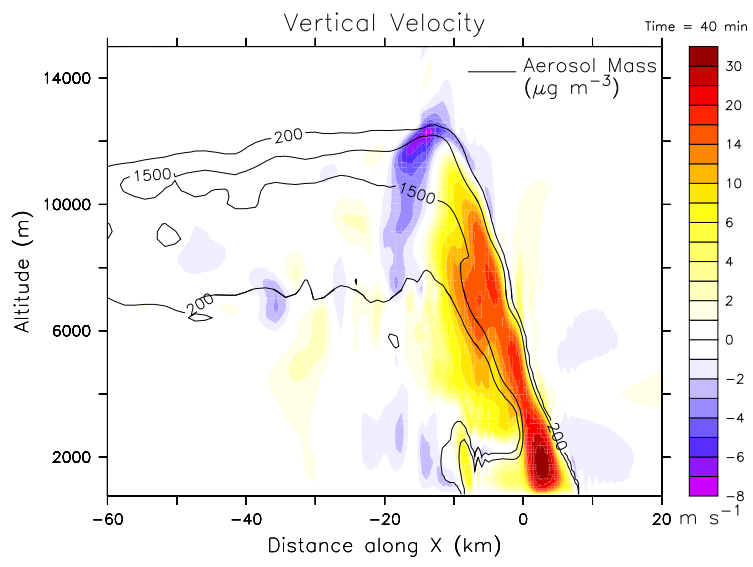

Fig. 10. Simulated updraft velocity (color coding) and aerosol mass concentration (contour lines) after $40 \mathrm{~min}$ along the cross section at $\mathrm{y}=0$.

the dynamics of the updraft region reaches a steady state. The maximum updraft velocity still oscillates at the end of the simulation indicating the complex dynamical coupling of the sensible heat flux from the fire with the atmospheric flow. At the end of the simulation, the maximum updraft, $\mathrm{w}_{\max }$, the mean updraft velocity, $\bar{w}$, and the integrated buoyancy, $I B$, are $38 \mathrm{~m} \mathrm{~s}^{-1}, 17.5 \mathrm{~m} \mathrm{~s}^{-1}$, and $1800 \mathrm{~J} \mathrm{~kg}^{-1}$, respectively. The difference between the CAPE of the ambient profile $\left(131 \mathrm{~J} \mathrm{~kg}^{-1}\right)$ and the calculated $I B$ can mainly be attributed to the emissions of sensible heat from the fire.

Figure 10 shows a cross section of the vertical velocity along the $y$-axis after $40 \mathrm{~min}$. The maximum vertical velocity is reached right above the fire, below the $2000 \mathrm{~m}$ level. At the tropopause, a region with downward vertical motions of about $6 \mathrm{~m} \mathrm{~s}^{-1}$ is simulated downwind of the fire. One has to note, that the interpretation of individual cross sections is complex, especially due to the asymmetric ambient flow.

In contrast to simulations of mid-latitude convection, the maximum vertical velocity is reached at lower levels in the case of fire-induced convection (between $1 \mathrm{~km}$ and $3 \mathrm{~km}$ compared to about $9 \mathrm{~km}$ in Wang, 2003 and Mullendore et al., 2005). This is explained by the significant acceleration by the heat flux from the fire. A second local maximum of the updraft velocity can be found at about $8 \mathrm{~km}$ (Fig. 10), which corresponds to the maximum of the updraft velocity in simulations of regular mid-latitude convection due to the release of latent heat. The different vertical profiles in the updraft velocity, in particular at cloud base, between regular mid-latitude convection and fire-induced convection potentially lead to differences in the cloud microphysical evolution in addition to the high number of smoke particles acting as CCN.

Shown in Fig. 11 is the simulated temperature anomaly after $40 \mathrm{~min}$ along the cross section at $\mathrm{y}=0 \mathrm{~km}$. The firereleased heat flux induces a temperature anomaly in the lower

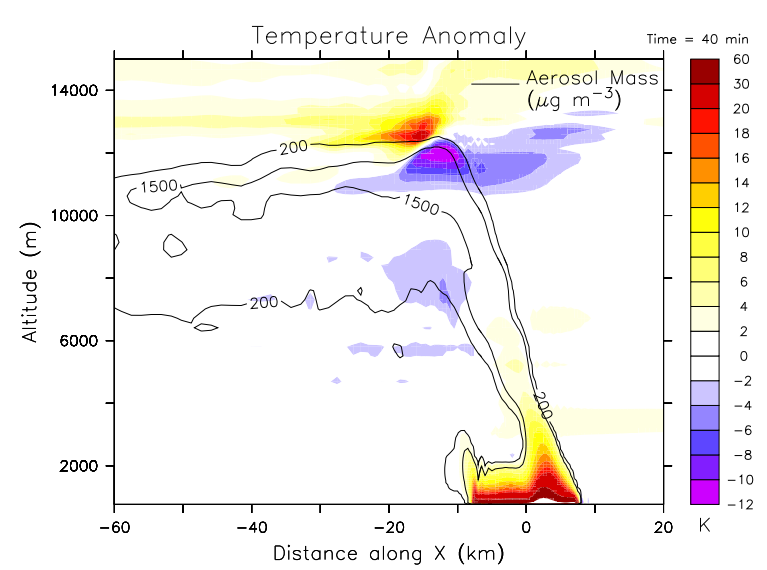

Fig. 11. Simulated temperature anomaly after $40 \mathrm{~min}$ along the cross section at $y=0$. Shown is the difference between the simulated and the initialized ambient temperature. Negative (positive) temperature anomalies are shown in blue (red).

$2 \mathrm{~km}$ of the rising plume with maximum values in the layer above the fire. About $1 \mathrm{~km}$ above the fire, the temperature anomaly has decreased to values smaller than $20 \mathrm{~K}$, at about $3 \mathrm{~km}$ it is only about $8 \mathrm{~K}$. In the upper part of the plume, a dipole-like structure of the temperature anomaly can be seen. This is associated with a gravity wave at the tropopause and will be presented in detail in Luderer et al. (2006b) ${ }^{2}$.

For photochemical reactions occurring in the smoke plume, this temperature enhancement can be regarded as small and can be neglected in photochemical models of young biomass burning plumes (Mason et al., 2001; Trentmann et al., 2005). The modification of the ambient temperature is, however, significant for the condensation of water vapor and the level of cloud base (see Sect. 5). The increased temperature leads to a delayed onset of condensation and a higher cloud base, thereby counteracting the effect of the water vapor emissions from the fire on the cloud base.

The contribution of the water vapor emitted by the fire to the total water vapor is shown in Fig. 12. The emitted water dominates the atmospheric water vapor concentration right above the fire, but due to mixing of the plume with environmental air masses, the contribution of the water vapor from the fire rapidly decreases at higher altitude. Above about $4000 \mathrm{~m}$, the contribution of water from the fire is less than $10 \%$ of the total water available in the plume. This analysis and a sensitivity study presented in Luderer et al. (2006a) shows that in the case of the Chisholm fire, the water vapor emitted from the fire does not have a significant impact on the evolution of the cloud and atmospheric dynamics. This result is consistent with the findings from previous model studies (Penner et al., 1986; Small and Heikes, 1988).

Entrainment of ambient air into the plume significantly reduces the contribution of the water vapor from the fire to the total water vapor in the plume. To investigate the amount of 


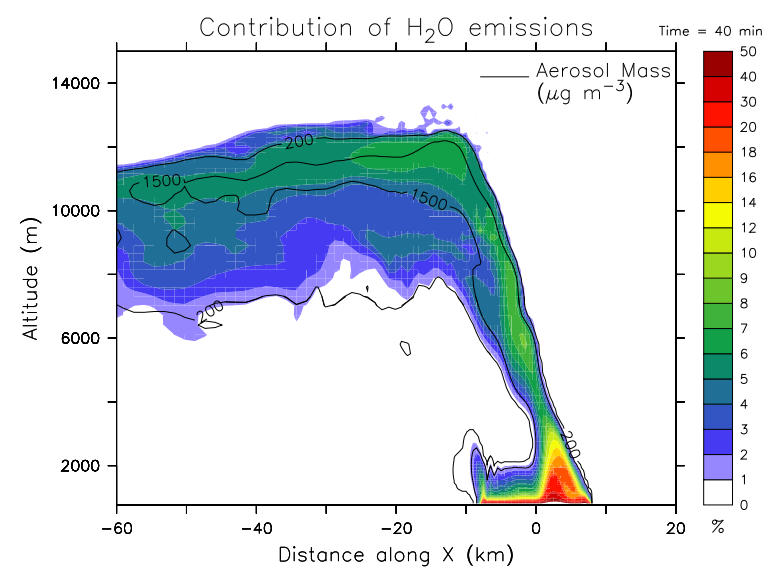

Fig. 12. Contribution of the water emitted from the fire to the total water in the plume from the Chisholm Fire along the cross section at $\mathrm{y}=0 \mathrm{~km}$.

mixing, six tracers were initialized within six separate layers of identical mass. The lower boundaries of the layers are the surface, $2.25 \mathrm{~km}, 4 \mathrm{~km}, 6.1 \mathrm{~km}, 8.9 \mathrm{~km}$, and $12.9 \mathrm{~km}$. The relative contribution of the different tracer masses in the smoke plume after 40 min of simulation is shown in Fig. 13. The air masses in the main outflow of the plume mainly originate from the two lower levels (Tracer I and Tracer II), each contributing about $30 \%$ to the total air mass in the plume. The significant contribution of the mid-level Tracer II indicates significant entrainment of ambient airmasses into the plume between $2.25 \mathrm{~km}$ and $4 \mathrm{~km}$. Additional contributions to the air in the outflow come from Tracers III, IV, and Tracer V. These findings are consistent with the modeling results from Mullendore et al. (2005), who also found significant entrainment of ambient air from the middle troposphere into the updraft and the outflow of convective systems. The significant contribution of mid-level air masses in the plume point to the potential importance of the background conditions, e.g. the humidity, for the evolution of the pyro-convection. The high amounts of entrainment also limit the use of the CAPE concept, which usually neglects entrainment, to characterize pyro-convection events. The non-negligible contributions of tracers V and VI in the smoke plume especially at elevations above $12 \mathrm{~km}$ give evidence for the occurrence of mixing processes and downward transport of stratospheric air at the tropopause level.

\section{Conclusions and outlook}

We presented three-dimensional model simulations of the pyro-convection associated with the Chisholm fire in Alberta, May 2001. During its most intense phase, the Chisholm fire burned 50000 ha of forested land within a few hours, resulting in the formation of an intense fire-induced cumulonimbus

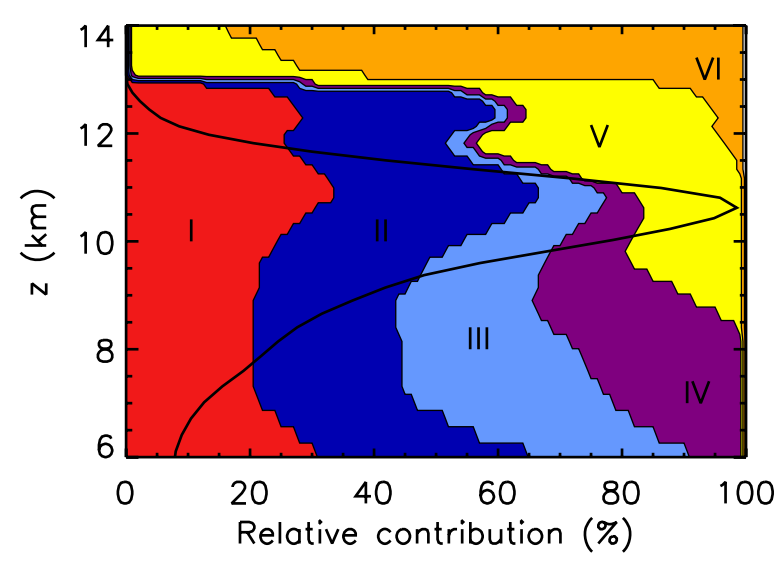

Fig. 13. Relative contribution of tracer airmasses in the plume from different atmospheric levels. Red: Tracer I, released between the surface and $2.25 \mathrm{~km}$; dark blue: Tracer II, $2.25 \mathrm{~km}-4 \mathrm{~km}$; light blue: Tracer III, $4 \mathrm{~km}-6.1 \mathrm{~km}$; purple: Tracer IV, $6.1 \mathrm{~km}-8.9 \mathrm{~km}$; yellow: Tracer V, $8.9 \mathrm{~km}-12.9 \mathrm{~km}$; orange: Tracer VI, above $12.9 \mathrm{~km}$. Also indicated is the horizontally integrated aerosol mass (black line).

(pyroCb). Using fire emissions based on available estimates for the amount of fuel burned and measurements obtained by a radiosonde at a distance of about $100 \mathrm{~km}$, the model is able to realistically simulate the formation and the evolution of the pyro-convection. In particular, the maximum penetration height of the pyro-convection (about $12.1 \mathrm{~km}$ ) compares well with radar observations, and the injection of smoke aerosol into the stratosphere is simulated in accordance with satellite observations. The character of the pyro-convection is different from regular mid-latitude convection. Mainly owing to the sensible heat emissions from the fire, the main outflow is significantly higher than the level of neutral buoyancy of the background atmosphere.

More modeling studies of this kind are required to fully understand the nature of pyro-convection. The intensity of pyro-convection determines the injection height of fire emissions, which is important for their atmospheric lifetime and impact. Injection of smoke from fires at high altitude into the atmosphere increases its lifetime compared to injection in the boundary layer and may result in hemispheric and seasonal effects of the smoke from a single pyroCb event on the atmosphere. PyroCb studies of the kind presented here, using different scenarios for the fire emissions and atmospheric conditions, will lead to a more realistic representation of fire emissions in larger scale models. Studies such as the present one also make it possible to take into account the small-scale processes in pyro-clouds that lead to a modification of the primary fire emissions (e.g., photochemistry, scavenging of soluble gases and particles). The investigation of these and other processes (e.g., aerosol-cloud interaction) using a combination of model simulations and field observations will lead to an improved representation of fire emissions in larger scale models and will also advance our understanding of these fundamental processes in regular convective clouds. 
Acknowledgements. J. Trentmann is indebted to the late P. V. Hobbs for his advice, support, und the opportunity to start this project while being part of the Cloud and Aerosol Research Group (CARG) at the University of Washington. Discussions with H. Wernli, A. Khain, M. Simmel, A. Rangno, D. Rosenfeld, D. Hegg, G. Mullendore, M. Stoelinga, E. Jensen, D. Diner, and M. Watton are highly appreciated. Valuable comments on the manuscript from two anonymous reviewers are also highly appreciated. J. Trentmann thanks the Alexander von Humboldt foundation for support through a Feodor Lynen fellowship. G. Luderer was supported by an International Max Planck Research School fellowship. Part of this research was supported by the German Ministry for Education and Research (BMBF) under grant 07 ATF 46 (EFEU), by the Helmholtz Association (Virtual Institute COSI-TRACKS), and by the German Max Planck Society. DWD and ECMWF are acknowledged for providing access to ECMWF Data.

Edited by: A. Stohl

\section{References}

Andreae, M. O. and Merlet, P.: Emission of trace gases and aerosols from biomass burning, Global Biogeochem. Cycles, 15, 955966, 2001.

ASRD: Final Documentation Report - Chisholm Fire (LWF-063), Forest Protection Division, ISBN 0-7785-1841-8, Tech. rep., Alberta Sustainable Resource Development, 2001.

Banta, R. M., Olivier, L. D., Holloway, E. T., Kropfli, R. A., Bartram, B. W., Cupp, R. E., and Post, M. J.: Smoke.Column Observations from Two Forest Fires Using Doppler Lidar and Doppler Radar, J. Appl. Meteorol., 31, 1328-1349, 1992.

Bigg, E. K.: The formation of atmospheric ice crystals by the freezing of droplets, Q. J. R. Meteorol. Soc., 79, 107-128, 1953.

Byers, H. R.: Elements of Cloud Physics, The University of Chicago Press, 1965.

Byram, G. M.: Combustion of forest fuels, in: Forest Fire Control and Use, edited by: Davis, K. P., McGraw-Hill, New York, 1959.

Chuang, C. C., Penner, J. E., and Edwards, L. L.: Nucleation Scavenging of Smoke Particles and Simulated Drop Size Distributions over Large Biomass Fires, J. Atmos. Sci., 49, 1264-1275, 1992.

Clark, T. L., Jenkins, M. A., Coen, J., and Packham, D.: A Coupled Atmosphere-Fire Model: Convective Feedback on Fire-Line Dynamics, J. Appl. Meteorol., 35, 875-901, 1996.

Clark, T. L., Coen, J., and Latham, D.: Description of a coupled atmosphere-fire model, Int. J. Wildland Fire, 13, 49-63, 2004.

Coen, J.: Simulation of the Big Elk Fire using coupled atmospherefire modeling, Int. J. Wildland Fire, 14, 49-59, 2005.

Crutzen, P. J. and Andreae, M. O.: Biomass Burning in the Tropics: Impact on Atmospheric Chemistry and Biogeochemical Cycles, Science, 250, 1669-1678, 1990.

Cunningham, P., Goodrick, S. L., Hussaini, M. Y., and Linn, R. R.: Coherent vortical structures in numerical simulations of buoyant plumes from wildland fires, Int. J. Wildland Fire, 14, 61-75, 2005.

Damoah, R., Spichtinger, N., Servranckx, R., Fromm, M., Eloranta, E. W., Razenkov, I. A., James, P., Shulski, M., Foster, C., and Stohl, A.: A case study of pyro-convection using transport model and remote sensing data, Atmos. Chem. Phys., 6, 173-185, 2006.
FIRESCAN Science Team: Fire in Ecosystems of Boreal Eurasia: The Bor Forest Island Fire Experiment, Fire Research Campaign Asia-North (FIRESCAN), in: Biomass Burning and Global Change, edited by: Levine, J. S., 848-873, MIT Press, Cambridge, Mass., 1996.

Fromm, M., Alfred, J., Hoppel, K., Hornstein, J., Bevilacqua, R., Shettle, E., Servranckx, R., Li, Z., and Stocks, B.: Observations of boreal forest fire smoke in the stratosphere by POAM III, SAGE II, and lidar in 1998, Geophys. Res. Lett., 27, 14071410, 2000.

Fromm, M., Bevilacqua, R., Servranckx, R., Rosen, J., Thayer, J. P., Herman, J., and Larko, D.: Pyro-cumulonimbus injection of smoke to the stratosphere: Observations and impact of a super blowup in northwestern Canada on 3-4 August 1998, J. Geophys. Res., 110, D08205, doi:10.1029/2004JD005350, 2005.

Fromm, M., Tupper, A., Rosenfeld, D., Servranckx, R., and McRae, R.: Violent pyro-convective storm devastates Australia's capital and pollutes the stratosphere, Geophys. Res. Lett., 33, L05815, doi:10.1029/2005GL025161, 2006a.

Fromm, M. D. and Servranckx, R.: Transport of forest fire smoke above the tropopause by supercell convection, Geophys. Res. Lett., 30, 1542, doi:10.1029/2002GL016820, 2003.

Gassó, S. and Hegg, D. A.: Comparison of Columnar Aerosol Optical Properties Measured by the MODIS Airborne Simulator with In Situ Measurements: A Case Study, Remote Sens. Environ., 66, 138-152, 1998.

Gostintesev, Y. A., Kopylov, N. P., Ryzhov, A. M., and Khazanov, I. R.: Numerical modeling of convective flows above large fires at various atmospheric conditions, Combust., Expl., Shock Waves, 27, 656-662, 1991.

Graf, H.-F., Herzog, M., Oberhuber, J. M., and Textor, C.: The effect of environmental conditions on volcanic plume rise, J. Geophys. Res., 104, 24 309-24 320, 1999.

Herzog, M., Graf, H.-F., Textor, C., and Oberhuber, J. M.: The effect of phase changes of water on the development of volcanic plumes, J. Volcanol. Geotherm. Res, 87, 55-74, 1998.

Herzog, M., Oberhuber, J. M., and Graf, H.-F.: A Prognostic Turbulence Scheme for the Nonhydrostatic Plume Model ATHAM, J. Atmos. Sci., 60, 2783-2796, 2003.

Hobbs, P. V. and Locatelli, J. D.: Ice nuclei from a natural forest fire, J. Appl. Meteorol., 8, 833-834, 1969.

Hobbs, P. V., Reid, J. S., Herring, J. A., Nance, J. D., Weiss, R. E., Ross, J. L., Hegg, D. A., Ottmar, R. D., and Liousse, C.: Particle and Trace-Gas Measurements in the Smoke from Prescribed Burns of Forest Products in the Pacific Northwest, in: Biomass Burning and Global Change, edited by: Levine, J. S., 697-715, MIT Press, Cambridge, Mass., 1996.

Hobbs, P. V., Sinha, P., Yokelson, R. J., Christian, T. J., Blake, D. R., Gao, S., Kirchstetter, T. W., Novakov, T., and Pilewskie, P.: Evolution of gases and particles from a savanna fire in South Africa, J. Geophys. Res., 108, 8485, doi:10.1029/2002JD002352, 2003.

Holton, J. R., Haynes, P. H., McIntyre, M. E., Douglas, A. R., Rood, R. B., and Pfister, L.: Stratosphere-troposphere exchange, Rev. Geophys., 33, 4, 403-439, 1995.

Immler, F., Engelbart, D., and Schrems, O.: Fluorescence from atmospheric aerosol detected by a lidar indicates biogenic particles in the lowermost stratosphere, Atmos. Chem. Phys., 5, 345-355, 2005. 
Jenkins, M. A.: Investigating the Haines Index using parcel model theory, Int. J. Wildland Fire, 13, 297-309, 2004.

Jost, H.-J., Drdla, K., Stohl, A., Pfister, L., Loewenstein, M., Lopez, J. P., Hudson, P. K., Murphy, D. M., Cziczo, D. J., Fromm, M., Bui, T. P., Dean-Day, J., Gerbig, C., Mahoney, J., Richard, E. C., Spichtinger, N., Pittman, J. V., Weinstock, E. M., Wilson, J. C., and Xueref, I.: In-situ observations of mid-latitude forest fire plumes deep in the stratosphere, Geophys. Res. Lett., 31, L11101, doi:10.1029/2003GL019253, 2004.

Khain, A., Pokrovsky, A., Pinsky, M., Seifert, A., and Phillips, V.: Simulation of Effects of Atmospheric Aerosols on Deep Turbulent Convective Clouds Using a Spectral Microphysics MixedPhase Cumulus Cloud Model. Part I: Model Description and Possible Applications, J. Atmos. Sci., 61, 2963-2982, 2004.

Lavoué, D., Liousse, C., Cachier, H., Stocks, B. J., and Goldammer, J. G.: Modeling of carbonaceous particles emitted by boreal and temperate wildfires at northern latitudes, J. Geophys. Res., 105, 26871-26 890, 2000.

Linn, R., Winterkamp, J., Colman, J. J., Edminster, C., and Bailey, J. D.: Modeling interactions between fire and atmosphere in discrete element fuel beds, Int. J. Wildland Fire, 14, 37-48, 2005.

Livesey, N. J., Fromm, M. D., Waters, J. W., Manney, G. L., Santee, M. L., and Read, W. G.: Enhancements in lower stratopsheric $\mathrm{CH}_{3} \mathrm{CN}$ observed by the Upper Atmosphere Research Satellite Microwave Limb Sounder following boreal forest fires, J. Geophys. Res., 109, D06308, doi:10.1029/2003JD004055, 2004.

Luderer, G., Trentmann, J., Winterrath, T., Textor, C., Herzog, M., Graf, H.-F., and Andreae, M. O.: Modeling of Biomass Smoke Injection into the Lower Stratosphere (Part II): Sensitivity Studies, Atmos. Chem. Phys., 6, 5261-5277, 2006a.

Manis, P. C.: Cloud heights and stratospheric injections resulting from a thermonuclear war, Atmos. Environ., 19, 1245-1255, 1985.

Mason, S. A., Field, R. F., Yokelson, R. J., Kochivar, M. A., Tinsley, M. R., Ward, D. E., and Hao, W. M.: Complex effects arising in smoke plume simulations due to inclusion of direct emissions of oxygenated organic species from biomass combustion, J. Geophys. Res., 106, 12 527-12 539, 2001.

McCarter, R. J. and Broido, A.: Radiative and convective energy from wood crib fires, Pyrodynamics, 2, 65-85, 1965.

Mitchell, R. M., O’Brien, D. M., and Campbell, S. K.: Characteristics and radiative impact of the aerosol generated by the Canberra firestorm of January 2003, J. Geophys. Res., 111, D02204, doi:10.1029/2005JD006304, 2006.

Morton, B. R., Taylor, S. G., and Turner, J. S.: Turbulent gravitational convection from maintained and instantaneous sources, Proc. R. Soc. Ser. A, 234, 1-23, 1956.

Mullendore, G. L., Durran, D. R., and Holton, J. R.: Crosstropopause tracer transport in midlatitude convection, J. Geophys. Res., 110, D06113, doi:10.1029/2004JD005059, 2005.

Murakami, M.: Numerical modeling of the dynamical and microphysical evolution of an isolated convective cloud - The 19 July 1981 CCOPE cloud, J. Met. Soc. Japan, 68, 2, 107-128, 1990.

Nedelec, P., Thouret, V., Brioude, J., Sauvage, B., Cammas, J.-P., and Stohl, A.: Extreme CO concentrations in the upper troposphere over northeast Asia in June 2003 from the in situ MOZAIC aircraft data, Geophys. Res. Lett., 32, L14807, doi:10.1029/2005GL023141, 2005.

Oberhuber, J. M., Herzog, M., Graf, H.-F., and Schwanke, K.: Vol- canic plume simulation on large scales, J. Volcanol. Geotherm. Res, 87, 29-53, 1998.

Packham, D. R.: Heat transfer above a small ground fire, Aust. For. Res., 5, 19-24, 1969.

Penner, J. E., Haselman, Jr., L. C., and Edwards, L. L.: SmokePlume Distribution above Large-Scale Fires: Implications for Simulations of "Nuclear Winter", J. Climate and Appl. Meteorol., 25, 1434-1444, 1986.

Penner, J. E., Bradley, M. M., Chuang, C. C., Edwards, L. L., and Radke, L. F.: A Numerical Simulation of the Aerosol-Cloud Interaction and Atmospheric Dynamics of the Hardiman Township, Ontario, Prescribed Burn, in: Global Biomass Burning: Atmospheric, Climatic, and Biospheric Implications, edited by: Levine, J. S., 420-426, MIT Press, Cambridge, Mass., 1991.

Pruppacher, H. R. and Klett, J. D.: Microphysics of Clouds and Precipitation, Kluwer Academics Publishers, 1997.

Radke, L., Hegg, D., Lyons, J., Brock, C., Hobbs, P., Weiss, R., and Rasmussen, R.: Airborne measurements on smoke from biomass burning, in: Aerosols and Climate, edited by: Hobbs, P. V. and McCormick, P., 411-422, A. DEEPAK Publishing, 1988.

Radke, L. F., Hegg, D. A., Hobbs, P. V., Nance, J. D., Lyons, J. H., Laursen, K. K., Weiss, R. E., Riggan, P. J., and Ward, D. E.: Particulate and Trace Gas Emissions from Large Biomass Fires in North America, in: Global Biomass Burning: Atmospheric, Climatic, and Biospheric Implications, edited by: Levine, J. S., 209-224, MIT Press, Cambridge, Mass., 1991.

Rosenfeld, D., Fromm, M., Trentmann, J., Luderer, G., Andreae, M. O., and Servranckx, R.: The Chisholm firestorm, Part I: Observed microstructure, precipitation and lightning activity of a pyro-CB, Atmos. Phys. Chem. Discuss., 6, 9877-9906, 2006.

Reid, J. S., Koppmann, R., Eck, T. F., and Eleuterio, D. P.: A review of biomass burning emissions part II: intensive physical properties of biomass burning particles, Atmos. Chem. Phys., 5, 799825, 2005.

Reisin, T., Levin, Z., and Tzivion, S.: Rain production in convective clouds as simulated in an axisymmetric model with detailed microphysics. Part 1: Description of the model, J. Atmos. Sci., 53, 497-519, 1996.

Seifert, A. and Beheng, K.: A two-moment cloud microphysics parameterization for mixed-phase clouds. Part1: Model description, Meteorol. Atmos. Phys., 92, 45-66, 2006.

Siebert, J., Timmis, C., Vaughan, G., and Fricke, K. H.: A strange cloud in the Artic summer stratosphere 1998 above Esrange $\left(68^{\circ} \mathrm{N}\right)$, Sweden, Ann. Geophys., 18, 505-509, 2000, http://www.ann-geophys.net/18/505/2000/.

Simmel, M. and Wurzler, S.: Condensation and activation in sectional cloud microphysical models, Atmos. Res., 80, 218-236, 2006.

Small, R. D. and Heikes, K. E.: Early Cloud Formation by Large Area Fires, J. Appl. Meteorol., 27, 654-663, 1988.

Stocks, B. J., Alexander, M. E., and Lanoville, R. A.: Overview of the International Crown Fire Modelling Experiment (ICFME), Can. J. For. Res., 34, 1543-1547, 2004.

Stohl, A., Bonasoni, P., Cristofanelli, P., et al.: Stratospheretroposphere exchange: A review, and what we have learned from STACCATO, J. Geophys. Res., 108, 8516, doi:10.1029/ 2002JD002490, 2003.

Textor, C., Graf, H.-F., Herzog, M., and Oberhuber, J. M.: Injection of gases into the stratosphere by explosive volcanic eruptions, J. 
Geophys. Res., 108, 4606, doi:10.1029/2002JD002987, 2003.

Textor, C., Graf, H. F., Herzog, M., Oberhuber, J. M., Rose, W. I., and Ernst, G. G. J.: Volcanic particle aggregation in explosive eruption columns. Part I: Parameterization of the microphysics of hydrometeors and ash, J. Volcanol. Geotherm. Res, 150, 359377, 2006a.

Textor, C., Graf, H. F., Herzog, M., Oberhuber, J. M., Rose, W. I., and Ernst, G. G. J.: Volcanic particle aggregation in explosive eruption columns. Part II: Numerical experiments, J. Volcanol. Geotherm. Res, 150, 378-394, 2006 b.

Trentmann, J., Andreae, M. O., Graf, H.-F., Hobbs, P. V., Ottmar, R. D., and Trautmann, T.: Simulation of a biomass-burning plume: Comparison of model results with observations, J. Geophys. Res., 107, 4013, doi:10.1029/2001JD000410, 2002.

Trentmann, J., Andreae, M. O., and Graf, H.-F.: Chemical processes in a young biomass-burning plume, J. Geophys. Res., 108, 4705, doi:10.1029/2003JD003732, 2003a.

Trentmann, J., Früh, B., Boucher, O., Trautmann, T., and Andreae, M. O.: Three-dimensional solar radiation effects on the actinic flux field in a biomass-burning plume, J. Geophys. Res., 108, 4558, doi:10.1029/2003JD003422, 2003 b.

Trentmann, J., Yokelson, R. J., Hobbs, P. V., Winterrath, T., Christian, T. J., Andreae, M. O., and Mason, S. A.: An analysis of the chemical processes in the smoke plume from a savanna fire, J. Geophys. Res., 110, D12301, doi:10.1029/2004JD005628, 2005.
Van Wagner, C. E.: The development and structure of the Canadian Forest Fire Weather Index System. Forestry Technical Report FTR-35, Tech. rep., Candian Forest Service, Petawawa National Forestry Institute, Chalk River, Ontario, 1987.

Waibel, A. E., Fischer, H., Wienhold, F. G., Siegmund, P. C., Lee, B., Ström, J., Lelieveld, J., and Crutzen, P. J.: Highly elevated carbon monoxide concentrations in the upper troposphere and lowermost stratosphere at northern midlatitudes during the STREAM II summer campaign in 1994, Chemosphere - Global Change Science, 1, 233-248, 1999.

Wang, P. K.: Moisture plumes above thunderstorm anvils and their contributions cross-tropopause transport of water vapor in midlatitudes, J. Geophys. Res., 108, 4194, doi:10.1029/ 2002JD002581, 2003.

Wooster, M. J.: Small-scale experimental testing of fire radiative energy for quantifying mass combusted in natural vegetation fires, Geophys. Res. Lett., 29, doi:10.1029/2002GL015487, 2002.

Wooster, M. J., Roberts, G., Perry, G. L. W., and Kaufman, Y. J.: Retrieval of biomass combustion rates and totals from fire radiative power observations: FRP derivation and calibration relationships between biomass consumption and fire radiative energy release, J. Geophys. Res., 110, D24311, doi: 10.1029/2005JD006318, 2005. 